\title{
Application of the Just-In-Time Approach to a Third- Generation Port
}

\author{
Yulia Panova \\ Department of Logistics and Commerce, Faculty of Railway Operation and Logistics, \\ Emperor Alexander I St. Petersburg State Transport University, St. Petersburg, Russia \\ Department of E-Commerce, \\ Luoyang Normal University, Luoyang City, Henan Province, China \\ E-mail: panovayulia87@gmail.com (Corresponding Author) \\ Per Hilletofth \\ Department of Industrial Engineering and Management, School of Engineering, \\ Jönköping University, Jönköping, Sweden \\ Department of Industrial Engineering and Management \\ University of Gävle, SE-801 76, Gävle, Sweden \\ E-mail: prof.p.hilletofth@gmail.com \\ Arina Panova \\ Faculty of Applied Optics, \\ ITMO University, St. Petersburg, Russia \\ E-mail: arina.panova97@gmail.com \\ Xu Hongsheng \\ Department of E-Commerce, \\ Luoyang Normal University, Luoyang City, Henan Province, China \\ Henan Key Laboratory for Big Data Processing \& Analytics of Electronic Commerce, \\ Luoyang 471934, China \\ E-mail:85660190@qq.com
}

\begin{abstract}
This paper investigates the feasibility of different logistics concepts applicable in a third-generation port (first-andforemost, just-in-time approach for a given case). In this regard, a simulation model imitating the work of a real thirdgeneration port was developed. Four experiments with proposed logistics solutions have been configured and evaluated in the simulation model. They differed by the size and number of shipping consignments to the port, deployed truck fleet, etc. The research shows that effective material transfers from the plant to the port can be provided, if a 'pulling' type of logistics system is applied instead of the traditional 'pushing' system. This alternative allows goods to be delivered just-in-time with the minimum labour costs and material resources.
\end{abstract}

Keywords: logistics, port generations, just-in-time concept, simulation modeling, 'pulling' and 'pushing' systems.

\section{INTRODUCTION}

Ports constitute a vital part of the transportation system (Gonzalez-Aregall, 2017; Kuznetsov and Galin, 2015). The role and function of the port within the transportation system has, however, evolved over time (Jakomin, 2003; Lee and Lam; 2015; Notteboom and Winkelmans, 2001; Tran et al.,
2012) and it is nowadays possible to distinguish five port types or generations (Jakomin, 2003; Montwiłł, 2014; Tran et al., 2012; Tran et al., 2011 UNCTAD, 1999). A firstgeneration port primarily includes cargo handling (loading, unloading) functions, serving as interchange point, while a second-generation port besides cargo handling function also includes customer-oriented commercial functions (Angeliki, 2005; Unescap.org, 2019). A third-generation port, additionally to previously mentioned functions, includes logistics and distribution with a predominant container specialization (Angeliki, 2005; Jakomin, 2003; Lam and Song, 2013; Tran et al., 2011).

In the fourth-generation ports, logistics and distribution functions transformed into integrated forms, bringing lean and agile practices into focus (Tran et al., 2011). The fifthgeneration ports referred to in the literature as nodal points of international supply chains (Montwiłl, 2014; UNCTAD, 1999), where the application of Lean Manufacturing and Six Sigma approaches still considered as relevant (Tran et al., 2011). Some others identify the sixth-generation ports, which conform to environmental protection law, integration of economic interest of the entire port community and further standardization of information sharing technologies (Kaliszewski, 2018). 
One of the most distinct characteristics of a thirdgeneration port is the co-located manufacturing and port operations. The idea of co-located manufacturing and port operations is not new and was introduced already after the II World War (Jakomin, 2003). Up until now, various types of manufacturing activities have been located in the port vicinity (Angeliki, 2005; Jakomin, 2003; Lam and Song, 2013; Tran et al., 2011). However, there is a lack of research about the integration and coordination of manufacturing and port operations in third-generation port that adds to a certain weakness of the third-generation port, where port supply center functions as an entity separate from the distribution chain (Accenture.com, 2016; Kaliszewski, 2018).

It could be assumed that information sharing technologies and total quality management practices are still held value for the third-generation ports as well. By the third phase of the development, ports became logistics centers, providing value-added services for customers. Therefore, just-in-time (JIT) principles of logistics, ensuring smooth flow of services and cargo are required in this generation of ports to reduce unnecessary waste and cargo lead time, ultimately resulting in the reduction of total costs and price, with a corresponding increase in productivity and profit (Tran et al., 2011).

The just-in-time concept started to occur in the vicinity of ports in the 1990s, bringing the benchmarking of this practice by seaports itself (Kaliszewski, 2018), thus improving the process of cargo and information flow in a manner aimed at eliminating wastefulness of resources and energy, as well as limiting downtimes (Paixão and Marlow, 2003). The existing literature on third-generation ports focuses on port integration into supply chains (Beškovnik and Twrdy, 2011; Hesse and Rodrigue, 2004; Notteboom and Rodrigue, 2008) and the employment of logistics and supply chain management apparatus for the conceptualization of ports development (Bichou and Gray, 2004; Lam and Song, 2013; Marlow and Casaca, 2003; Panayides and Song, 2009; Song and Panayides, 2012; Tran et al., 2011; Tran et al., 2012). Recent studies of ports integrated into a network consider quality management practices in terms of a JIT approach, quick response, leadtime management, lean and agile logistics (Lam and Song, 2013; Marlow and Casaca, 2003; Tran et al., 2011; Tran et al., 2012). Meanwhile, little emphasis has been put on what types of logistics set-ups are feasible in third-generation ports.

This study aims to investigate the feasibility of different logistics approaches (mainly, 'pulling' and 'pushing' systems) for a third-generation port. To achieve this goal, the following questions are addressed in the article: Why the application of JIT concept is reasonable for the organization of interconnections between the port and plant? How an integrated organization of production and port-related processes can be planned? So as to access the effectiveness of proposed logistics solutions, a discrete event simulation model of a real third-generation port was developed in AnyLogic. A logistics system consisting of a manufacturer co-located with the port of Ust-Luga (Russia) was used. The manufacturer exports to Sweden. Four experiments with different logistics approaches have been carried out for the organization of a process, connecting port with the industrial zone. These experiments were configured and evaluated with the help of the simulation model. The input for the simulation model comes from various databases and was implemented through constant and random variables.

The remainder of this paper is structured as follows. Section 2 provides a literature review on port development via different generations. Section 3 makes an emphasis on logistics approaches in ports. Section 4 considers the simulation modelling case: Ust-Luga port, which undergoes the transformation to the status of the third-generation port and experiences the integration of its maritime processes with the proposed plant on the ground of principles of the 'pulling' type logistic system. In this section, we also describe a basic framework for the researched area, specifically, the development of the discrete event simulation model and experiments with it. In Section 5, the findings highlight the application of the just-in-time approach, which is natural for the 'pulling' type logistics system considered in the case. Its effectiveness for the coordination of the supply of finished products from the plant to the port is justified by simulation modelling, which is discussed in Section 6. Finally, conclusions and further research are provided in Section 7.

\section{LITERATURE REVIEW ON THE PORT DEVELOPMENT PRACTICES}

Ports are naturally evolving over time as any alive systems under influences from the external and internal environments. Their functions are changing to adapt to the dynamic ecosystems (Jakomin, 2003; Lee and Lam; 2015; Notteboom and Winkelmans, 2001; Tran et al., 2012). As a matter of fact, the evolution of ports' generations receives attention among maritime scholars (Jakomin, 2003; Montwiłł, 2014; Tran et al., 2011; Tran et al., 2012; UNCTAD, 1999). Nowadays, targeting the fifth-generation port (5GP) practices (Flynn et al., 2011; Lee and Lam, 2016) becomes the inevitable norm, as they can be witnessed, starting from the 2000s.

Since the 1950s the ports' roles have been changed every decade. By 60s, the functions of 1 st generation ports (1GP) were built in solid forms. Their extension from primarily cargo handling continued in forthcoming years to commercial and industrial functions, adhered to the 2GP, which were developed in 1960-70s. Then, 3GP appeared (Angeliki, 2005; Jakomin, 2003; Lam and Song, 2013; Tran et al., 2011), with predominant container specialization and emphasis on logistics and distribution functions that afterwards transformed into integrated forms. As a result, 4GP as nodal points of international supply chains evolved during 1990-2000s (Montwiłł, 2014; UNCTAD, 1999).

With the evolution of the ports, the port clusters also have undergone significant changes from generation to generation. According to Lam and Zhang (2011), the Rotterdam and London being the pioneers of the firstgeneration maritime cluster (1GMC) nowadays are already representing respectively the group of 3GMCs (Hamburg, Germany; Hong Kong, China; New York/New Jersey, USA; Piraeus, Greece; Singapore; Shanghai, Mainland of China; Tokyo, Japan) and 4GMC (Oslo, Norway). The status of 1 GMC belongs to Dublin (Ireland) and Selangor (Malasia), while the 2GMC assigned to Antwerpen (Belgium); Kaoasiung (Taiwan) and Osaka (Japan). 
Due to the recent changes, ports became logistics centers viewed in the context of the global supply chains (Lam and Song, 2013; Tran et al., 2011; Tran et al., 2012). Their competitiveness is assessed inseparably from integration processes (Madani, 2018; Panayides and Song, 2009; Song and Panayides, 2008). If previously, the attention was paid to the operational competitiveness and geographical location's benefits of the ports itself, nowadays, the focus is shifted to the total quality management of the whole supply chain, where a port is considered as one of the elements integrated with other SC members to form a network.

Many researchers proved that the conceptualization of ports development from a logistics and supply chain management perspective is reasonable and justified (Bichou and Gray, 2004; Lam and Song, 2013; Marlow and Casaca, 2003; Panayides and Song, 2009; Song and Panayides, 2012; Tran et al., 2011; Tran et al., 2012). Recent studies of ports integrated into a network also consider quality management practices in terms of a just-in-time approach, quick response, lead-time management, lean and agile logistics (Lam and Song, 2013; Marlow and Casaca, 2003; Tran et al., 2011; Tran et al., 2012). Moreover, for the fifth stage of port evolution, the approaches, which are mostly used by manufacturers, are applicable. These are Lean manufacturing and Six Sigma philosophy up to quality management along the whole supply chain (Tran et al., 2011).

In essence, the lean concept focuses substantially on the process flow and synchronization of demand and production that allows the elimination of waste occurring in all processes. At the same time, both approaches facilitate the JIT services that in turn provide the reduction of total cost and price, with a corresponding increase in productivity and profits. Still, so far, there has not been any evidence in the literature that such quality practices had been undertaken by ports of the fifth-generation (Tran et al., 2011). This study is not an exception, since it only outlines the benefits of these approaches from a theoretical point of view, contributing to the similar research, concerning the positive impact of simulation for the development of lean ports and lean ports networks (Casaca, 2005). Meanwhile, in contrast to the previous research that considers them in terms of port integration into supply chains (Beškovnik and Twrdy, 2011; Hesse and Rodrigue, 2004; Notteboom and Rodrigue, 2008), this research justifies their application for testing the influence of integrating the production facilities with the port operations.

\section{PROPOSED LOGISTICS APPROACHES FOR THE THIRD- GENERATION PORT}

To minimize costs, the principles of integrated logistics in the organization of deliveries of products for export can be used. Since the immediate goal of logistics is the delivery of goods just-in-time with the minimum costs of labour and material resources, JIT principle can be used to deliver finished products from the plant to the port (Panova, 2011). The just-in-time strategy is one of the main strategies for integrated logistics planning in supply chains (Dybskaya $e t$ al., 2008; Lukinskiy, 2008). It was introduced by the Japanese automobile concern Toyota, and widely used in the 1960s (Waters, 2009), then spread to non-Japanese cultures (Arumsari et al., 2019). Its purpose is to carry out purchases and deliveries following actual needs, eliminating the waste along the supply chain.

Logistic systems that use the principle of the just-intime concept are 'pulling' systems, in which the placing of orders for the replenishment of stocks of material resources (Lukinskiy et al., 2016a) or finished products occurs when their quantity in certain parts of the logistics system reaches a critical level (Lukinskiy et al., 2016b; Waters, 2009). In this case, stocks are 'pulled' through distribution channels from suppliers of material resources or in the company's distribution system. In a traditional process, each operation has a timetable of work that must be finished in a given time. Finished items are then 'pushed' through to form a stock of work in progress in front of the next operation. The 'push' and 'pull' systems are applied to the concept of dry ports acting as buffers for import-oriented or export-oriented seaports, respectively (Notteboom and Yang, 2017; Panova, 2009; Panova, 2016; Rodrigue, 2008; Roso, 2009).

The 'pull' system can be used to arrange the efficient maritime export operations, the delivery of sandwich panels to the port from the plant. For each dispatch, it will be necessary to determine the transit time to the port. Then, in the reverse order, taking into account the moment of the start of the discharge of the first batch, the time for starting the loading of the panel trucks for the next batch should be calculated, considering the loading capacities in the warehouse of the plant. If the shipping lot is large, then assuming the number of available trucks used to deliver cargo to the port, as well as the speed of transshipment, the next approach moment is calculated, based on which the loading time of the remaining trucks is determined (Figure 1).

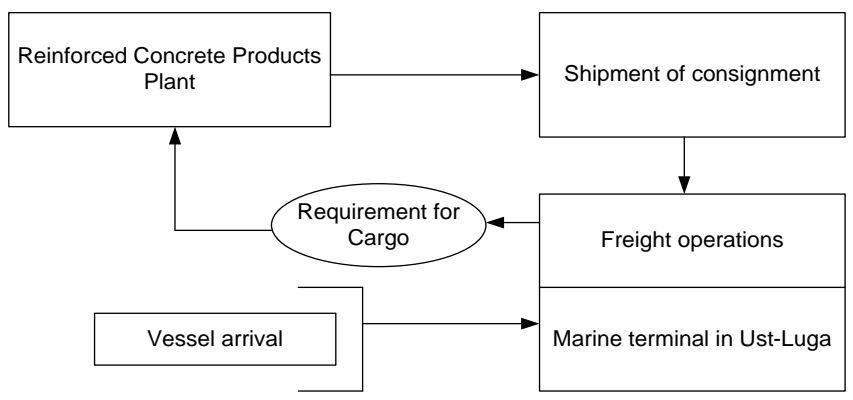

Figure 1 The scheme of the process, connecting port and industrial zone.

Source (original; modified for the case of Ust- Luga): Panova (2009).

According to Figure 1, the logistics-oriented organization of work involves planning the delivery of goods, starting from the consignee located in the port, i.e. based on its actual demand for the quantity and quality of the cargo, and further to the shipper (the plant). This corresponds to the 'pulling' type of production process control system, in which each subsequent technological section draws from the previous only the right amount of cargo for a particular consumer and at the right time (Isaeva, 2017; Panova, 2011; Panova et al., 2016).

Following this method of organizing the interaction of participants in the logistics chain, a part of the cargo of ' $A$ ' 
size is shipped and delivered before the arrival of the vessel, the remaining part of the cargo is ' $B$ ' when the vessel is already moored to the berth and the cargo ' $\mathrm{A}$ ' is transshipped (Panova, 2009). The transition from traditional systems of production process control of 'pushing' type to 'pulling' type systems will ensure efficient transfer of materials between the participants of the transportation process, minimizing total costs. For the application of this approach, the simulation experiments with the model will be carried out.

It should be noted that simulation has been used by many researchers to test logistics concepts in different spheres, because the simulation is considered as one of the most effective approaches for the study of complex systems at the stage of their design and development (Panova and Hilletofth, 2018). This approach was chosen by Karsaev et al. (2016) for the testing of the relay transportation technology by the agent modeling approach. Andronov (2013) applied simulation so as to test 'just in time' approach also in the transport sphere and synchronize the work of carriers and warehouses. Kaigorodtsev and Rakhmangulov (2009) applied simulation modeling in pre-project evaluation of the distribution center of industrial enterprise products.

Simulation modeling finds its application in the maritime sphere, too. Novorossiysk container terminal was simulated to assess the effectiveness of design solutions for the creation and modernization of cargo terminals (Containerbusiness.ru, 2011). In the process of experiments with the model, the effect of 'digging' containers in the stack during their multi-tiered storage was revealed, an algorithm for justifying the optimal stacking height for various storage systems was proposed. Suslov (2009) apart from this case additionally cites an example from logistics in the production sphere, e.g. the technological line for the manufacturing of foam concrete by CET Holding. The author concludes that business is a field for experiments. But it is better to conduct them on simulation models. On the whole, it is safe to conclude that simulation modeling in logistics covers such aspects as planning and scheduling; transportation and fleet management, transport network management, supply chain management, development of warehouses and terminals (Anylogic.ru, 2019; Tikhonova and Minkova, 2016).

\section{SIMULATION MODELING}

\subsection{Case}

As a case for the simulation model, the port of Ust-Luga was used. It is expected to become the core of the transport and logistics cluster of the Russian North-West region (Isaeva, 2017; Makrushina, 2016; Neustroeva, 2011). Current analysis of existing cargo flows showed that the port is on the $2^{\text {nd }}$ place in Russia in terms of processing the entire range of goods, and on the $6^{\text {th }}$ place by processing high-yield cargo transported in containers (in which only $1 \%$ of the port throughput; Table 1).

In the long term, it is expected the port of Ust-Luga will become the largest in Russia and the Baltic Sea port for processing containers (2.6 million TEU per year). The optimistic forecasts on the development of Ust-Luga port can be feasible if take into account the presence of several favourable conditions that facilitate the implementation of ambitious plans: 1) The possibility of reducing the transit time on the route between the main ports of Europe and UstLuga by at least 1-2 days, as compared to calling at the port of St. Petersburg since the port of Ust-Luga is closer to the ports of Europe by 40 miles. 2) Large depths of the port water area $(17 \mathrm{~m})$ in combination with a short approach channel $(3.7 \mathrm{~km})$ make the port of Ust-Luga under construction the only Russian port in the Baltic, capable of accepting dry cargo vessels of up to 75,000 dwt and liquid cargo ships of up to 120,000 deadweight tons. 3) The presence of a second approach channel providing the circular movement of vessels. 4) Year-round operation with a short period of ice wiring (about 40 days). 5) Scheme of cargo flows, bypassing the extremely overloaded St. Petersburg transport hub.

Table 1 Share of containerized cargo from the total turnover of ports.

\begin{tabular}{|c|c|c|c|c|}
\hline Rank & Port & $\begin{array}{c}\text { The volume of cargo } \\
\text { handling, } \\
\text { million tons }\end{array}$ & $\begin{array}{c}\text { The volume of cargo } \\
\text { handling in containers, } \\
\text { million tons (TEU) }\end{array}$ & $\begin{array}{c}\text { The share of } \\
\text { containerized cargo in } \\
\text { the total cargo } \\
\text { turnover, } \%\end{array}$ \\
\hline 1 & St. Petersburg & 59.3 & $29.94(2130723)$ & $51 \%$ \\
\hline 2 & Novorossiysk & 154.9 & $7.82(943984)$ & $5 \%$ \\
\hline 3 & Vladivostok & 21.2 & $8.42(754894)$ & $40 \%$ \\
\hline 4 & Vostochny & 69.2 & $4.66(419195)$ & $7 \%$ \\
\hline 5 & Kaliningrad & 14.1 & $1.21(276429)$ & $9 \%$ \\
\hline 6 & Ust-Luga & 98.7 & $0.83(97630)$ & $1 \%$ \\
\hline 7 & Dudinka & 1.3 & $0.90(67988)$ & $69 \%$ \\
\hline 8 & Korsakov & $1.8^{* *}$ & $0.63(82800)^{* *}$ & $39 \%$ \\
\hline 9 & Petropavlovsk-Kamchtsky & $1.3^{* *}$ & $0.61(69131)^{* *}$ & $47 \%{ }^{* *}$ \\
\hline 10 & Murmansk & 60.7 & $0.86(40610)$ & $1 \%$ \\
\hline 11 & Magadan & 1.4 & $0.63(61608)$ & $45 \%$ \\
\hline 12 & Arkhangelsk & $1.6^{* *}$ & $0.36(30789)^{* *}$ & $23 \%{ }^{* *}$ \\
\hline 13 & Bronka & 3.0 & $2.94(182900)$ & $98 \%$ \\
\hline
\end{tabular}


In this regard, an integrated approach is used to the development of the port territories, covering a total area of more than 3000 hectares, with a cargo airport, dry port, industrial and logistics complex, industrial parks, aviation warehouse, and customs terminals, wind generation, residential, and recreational complexes. These industrial facilities are planned close to Ust-Luga port. In the current study, the specific case of plant allocation in the port vicinity will be considered. That is the Betset plant - one of the most modern, specializing in single- and multilayer wall panels (Dp.ru, 2016a, 2016b; Betset.fi, 2016). Its products will be delivered to Sweden via the port of Ust-Luga to Stockholm.

For the transport of sandwich panels, road or sea transport can be used. Sea delivery of goods to Sweden is carried out, as a rule, for 5 - 9 days, while the time of delivery of goods by road is 3 to 7 days from St. Petersburg (Vinceraspb.ru, 2016). Based on the analysis of transportation schemes by road and sea (Logist, 2016; Searates, 2016), it is found that the delivery of panels to Stockholm from the port of Ust-Luga can be more profitable in terms of cost and distance of transportation, which is $100 \mathrm{~km}$ shorter than from the port of St. Petersburg (627 and $727 \mathrm{~km}$ respectively) and $350 \mathrm{~km}$ less than in the scheme of transportation using mainly road transport. The option of delivery by sea is almost $50 \%$ cheaper than road transport (Vincera-spb.ru, 2016).

\subsection{Model}

The object of the research, i.e. a factory for the production of reinforced concrete products (wall sandwich panels) subjected for the export through the port of Ust-Luga was analyzed via simulation modelling. This research method was chosen as a result of forming a framework, or so-called research subject, which helped to study the problem from the scientific point of view. The simulation environment was used because it is almost impossible to imagine the implementation of the principles of integrated logistics without the appropriate computer-based decision support systems.

One of the most common simulation systems developed in Russia and distributed abroad is the AnyLogic software. This computer package provides the simulation which can be grounded on one of the four approaches (system dynamics; discrete-event modelling; modelling of dynamic systems; agent-based modelling) or their combination within one model (AnyLogic.ru, 2019; Ekyalimpa et al., 2016; Hilletofth and Lättilä, 2012). For the simulation of a complex system (plant - port) and corresponded integration of production and transport processes, the discrete-event modelling has been used in AnyLogic. The operation of the simulated system was based on the process flow of the system being modelled (Fig. 2).

The simulation model was used for the dynamic analysis of the system. The material, financial and information flows were considered in the system as dynamic entities that occur with some periodicity and are transformed in the process. Thus, the relevance of the use of dynamic analysis in the development of integrated systems was explained by the need to reduce the inter-operational costs that are associated with the use of resources in different processes. At the same time, the resources that provide the business process were treated as static entities, because despite the change in time, these objects, e.g. equipment, stocks, etc. were used for several production cycles in the system.

In the accelerated time, there was a movement of objects passing through the blocks of the structure, similar to what happens in real-time. The aim of the simulation of the system under consideration was to design and analyze the production system of the enterprise located in the vicinity of the port and simulate the activity of the internal logistics of production (Panova et al., 2016), as well as planning of supply of products to the port.

The model includes the two Event blocks. With the help of one event, the arrival of the vessel at the set time is generated, and with the second event, the loading operations begin immediately after the arrival of the vessel. Hold blocks have been added to fix the moment when the accumulation of the shipping consignment is provided (hold) and the vessel is ready to perform loading operations (hold1). The blocks of the process modelling library describe the delivery of panels to the port (the top line), while the bottom line is used to reflect the process of ship loading (Fig. 3).

The model was verified and validated although Sterman (2000) argues that true validation and verification is impossible, as models are always some sort of abstractions from some person's mental models, and thus all models are wrong. According to Barlas and Carpenter (1990), verification refers to internal consistency, whereas validation refers to the justification of knowledge claims. In other words, verification is the process of evaluating a system or component during or at the end of the development process to determine whether it satisfied specified requirements. To perform this process, one can answer the question: Are we building the product in the right way? For example, in this case, we checked whether we have all the required model blocks to represent the system, such as manufacturing of cargo, loading zone, transportation of cargo to the port, storage zone, the arrival of the ship to the port, accumulation of the shipping consignment at the seaport terminal.

Validation is the second step in the model development that refers to checking how the software product meets the expectations and needs of users. Particularly, we answer the question: Whether there is an effect of what we have or there is no effect? For example, if instead of the 'plant-port system' the bicycle was under development, then the process would be as follows. After checking all components at verification stage (pedals, saddle, chain, etc.), at the validation phase, one would test it by motion (Goes? Not going?). In the current model, we asserted that there is confidence in its usefulness for the purpose of reducing operating costs. With the help of different scenarios of logistics processes in the port, the preferable scenario was identified. Moreover, the model was validated by comparing the system configuration inside the decision support system against real systems. At the same time, during the design process of the model, some existing cases were used to validate the data of the model. Finally, the intermediate calculations have worked as a validation tool to see that the spreadsheet gives accurate results (Lättilä, 2012). Specifically, the findings of the model were identified with the help of variables represented by the key performance indicators of the system (Table 2). 


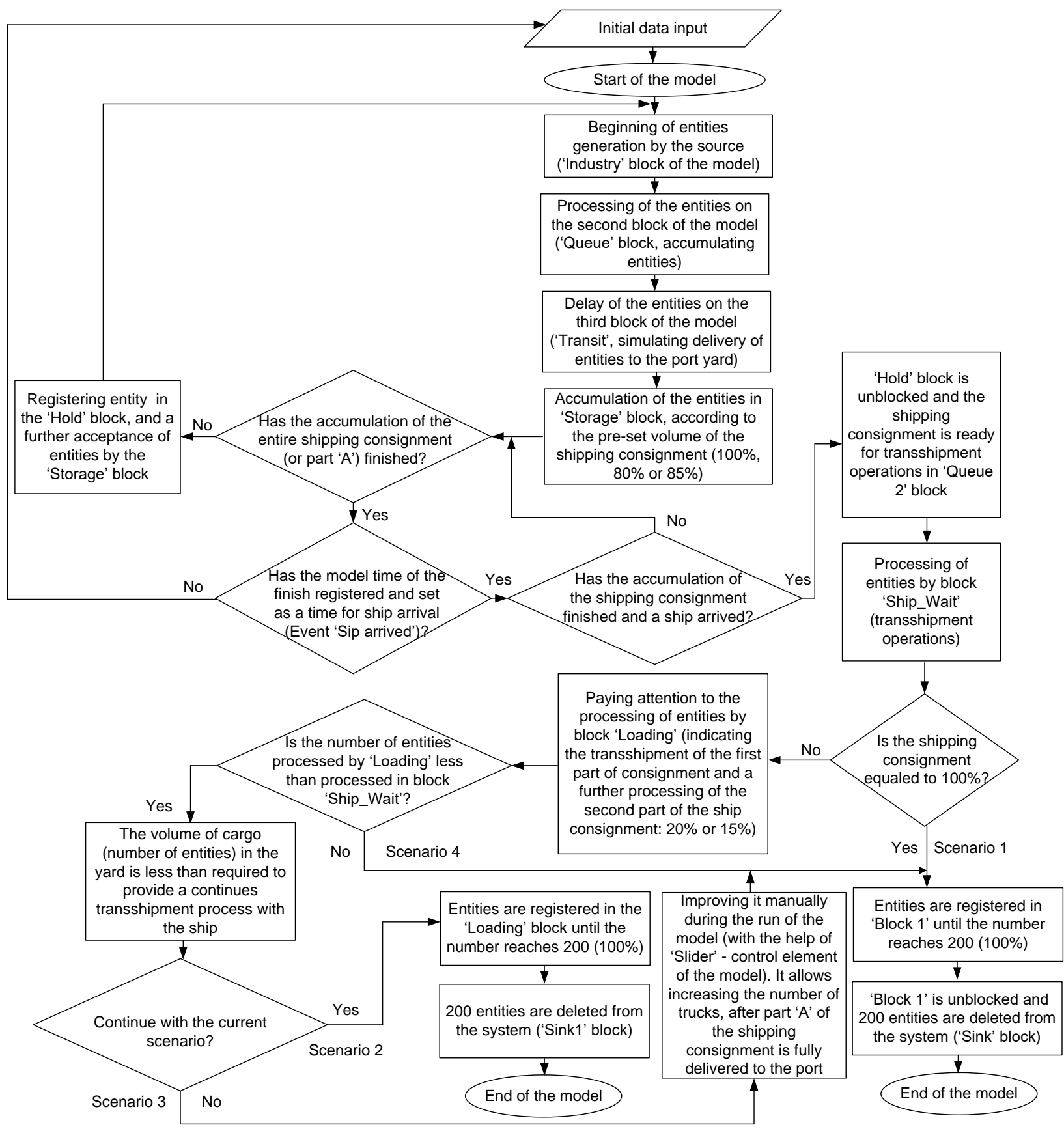

Figure 2 Process flow of the system being modelled.

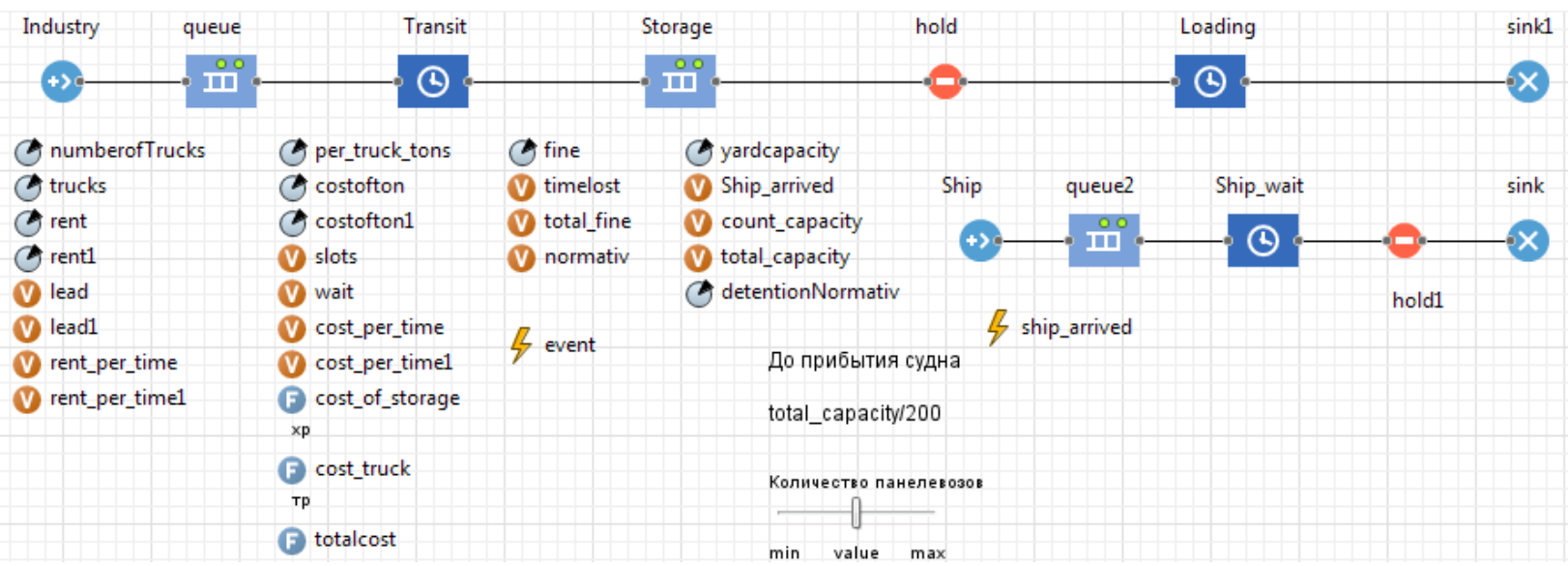

Figure 3 Discrete-event model of shipping consignment accumulation. 
Table 2 Key performance indicators (KPI) of the system

\begin{tabular}{|l|l|}
\hline KPI & Notification in the model \\
\hline The time that 5 trucks-panellists spent on a voyage & lead \\
\hline The time that additional panellists spent on the voyage & lead1 \\
\hline The cost of using 5 panellists on a voyage & rent_per_time \\
\hline The cost of renting additional panellists & rent_per_time1 \\
\hline The capacity of a storage yard in the port & slots \\
\hline The time that the panel stays in the warehouse & wait \\
\hline Cost of storing panels within two days & cost_per_time \\
\hline The cost of storing panels starting from the 3 ${ }^{\text {rd }}$ day & cost_per_time1 \\
\hline Demurrage of vessel & timelost \\
\hline A total amount of penalty & total_fine \\
\hline Ship's arrival and handling process & Ship_arrived \\
\hline The number of loaded panel blocks per vessel & count_capacity \\
\hline Total number of submerged blocks of panels per vessel & Total_capacity \\
\hline
\end{tabular}

Table 3 Input data of the model

\begin{tabular}{|l|l|l|}
\hline Parameter & Value & Constant/ Random Variable \\
\hline $\begin{array}{l}\text { Time for one delivery from the plant to } \\
\text { Ust-Luga }\end{array}$ & $\begin{array}{l}\text { On average four hours, taking into account } \\
\text { the empty voyage }\end{array}$ & $\begin{array}{l}\text { Described by triangular distribution } \\
\text { (min time }-3.5, \text { mode }-4, \text { and max }-4.5)\end{array}$ \\
\hline $\begin{array}{l}\text { Loading time of each panel block per } \\
\text { vessel (four panels in the block) }\end{array}$ & On average 15 minutes & $\begin{array}{l}\text { Described by triangular distribution } \\
\text { (min time -12, mode }-15, \text { and max }-16)\end{array}$ \\
\hline The number of trucks & 5 units & Fixed value \\
\hline The cost of truck operation & 1000 Rubles per hour & Fixed value \\
\hline $\begin{array}{l}\text { The cost of renting additional truck- } \\
\text { panellists }\end{array}$ & 1500 Rubles per hour & Fixed value \\
\hline $\begin{array}{l}\text { The amount of tone transported by one } \\
\text { truck }\end{array}$ & 16 tones & Fixed value \\
\hline Cost of storage of one ton & $\begin{array}{l}5 \text { Rubles/hour for two days, from the } 3 \text { rd } \\
\text { day - } 50 \text { Rubles/hour }\end{array}$ & Fixed value for each period \\
\hline $\begin{array}{l}\text { The capacity of the storage area in the } \\
\text { port }\end{array}$ & $\begin{array}{l}\text { the maximum value equals the size of the } \\
\text { ship consignment, } 800 \text { panels or } 3000 \text { m }{ }^{2}\end{array}$ & Fixed value \\
\hline Preferential time of the ship's idle time & $\begin{array}{l}\text { One hour after the laytime expiration }(24 \\
\text { hours) }\end{array}$ & Fixed value \\
\hline The penalty for idle time & 6500 Rubles for one hour of demurrage & Fixed value \\
\hline
\end{tabular}

For the development of the model, it was assumed that finished products from the storage zone of the manufacturer will be sent to the port of Ust-Luga employing road transport. In order to deliver the ship's batch to the port $\left(3000 \mathrm{~m}^{2}\right.$ in size), there are 5 trucks available. Since ship consignment equals 3000 cubic meters and one panel is 3.75 cubic meters, then 800 of panels should be sent to the port. Delivery of finished products is carried out by trucks-panellists, on which it is possible to load 4 panels. Based on the volume of the ship's consignment, it will be necessary to make 200 trips. The export of panels will be carried out from the plant located on the $22^{\text {nd }}$ kilometre of the Kyiv highway on a land of 14 hectares. The vessel arrives at the set time, orienting on which it is required to organize the delivery of goods to the port. To solve this task, input data for the model, in addition to the volume of the shipping consignment, was taken into account (Table 3).

\subsection{Experiments}

The experiment included the set of values of parameters, such as the intensity of the movement of objects, time, the number of resources, and the subsequent playback of the model in time, with observation and obtaining of statistics as an outcome. To select the most rational option of accumulation of the shipping consignment, several experiments with the model have been carried out.

\subsubsection{Experiment 1}

The whole ship consignment $(3,000$ cubic meters $)$ is taken to the port before the ship's arrival. The scheme of transshipment process management is depicted in Figure 4.

Since one panel is 3.75 cubic meters, then the number of panels is 800 . If there are four panels on the truck, it is necessary to provide 200 trips. Under this condition, 200 trips will be required before the ship arrives. There are 5 trucks-panellists, belonging to the company (costs per 1 hour of using the panellist - 1000 Rubles), time for 1 delivery from the plant to Ust-Luga (four hours with an empty journey). The cost of storing one ton is 5 Rubles per hour for two days, from the $3^{\text {rd }}$ day is 50 Rubles per hour.

With the help of the model, the total time for the delivery of the entire batch by the time of the vessel arrival was determined. It should be noted that just one run of the model with constant parameters was insufficient. The reason is that during the run of the model, random probability samples were used. Hence, the output from one experiment would be the only individual result of a random variable with a large variance. Therefore, in order to obtain more reliable data, further 5 runs of the model were carried out (Table 4). 


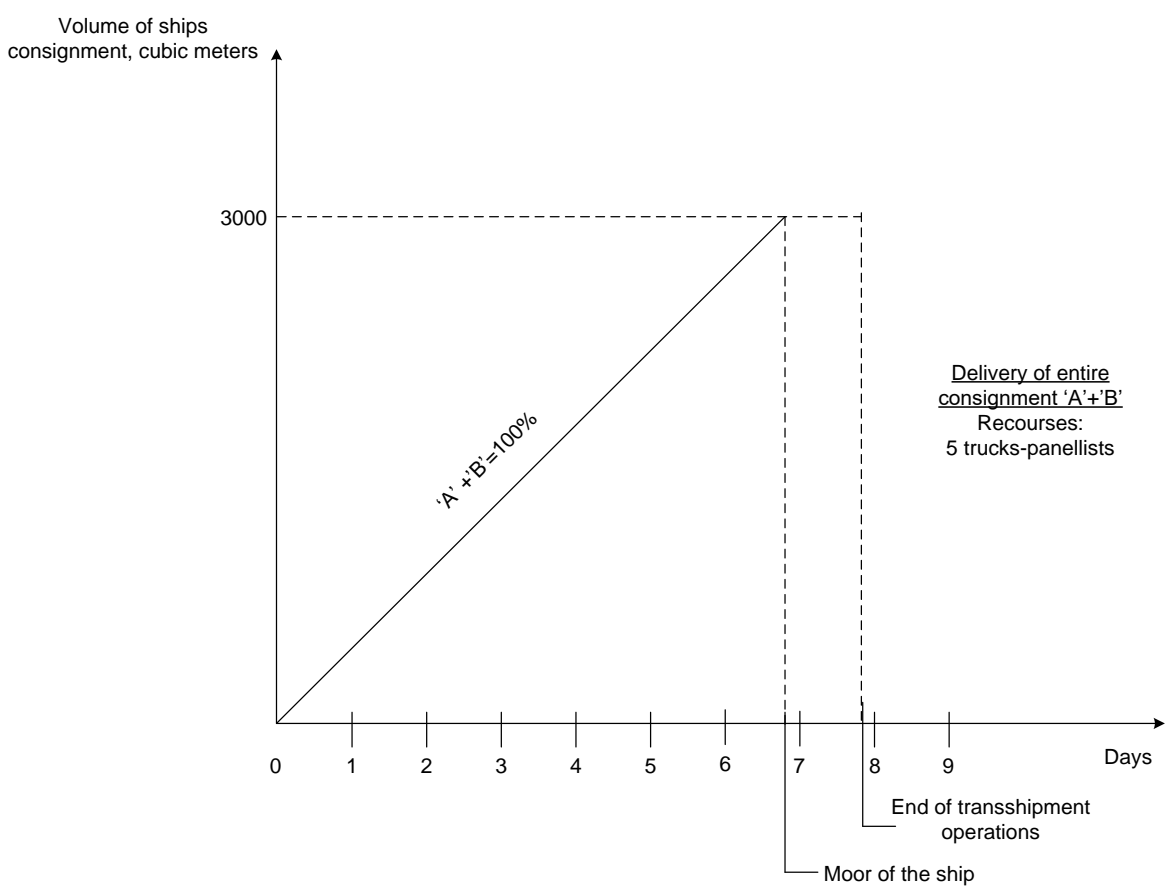

Figure 4 Scenario 1 - entire batch $(100 \%)$ is delivered to the port before the ship arrival

Table 4 Output of the experiments, representing scenario 1

\begin{tabular}{|l|c|c|c|c|c|c|}
\hline Experiment & $\mathbf{1}$ & $\mathbf{2}$ & $\mathbf{3}$ & $\mathbf{4}$ & $\mathbf{5}$ & Mean value \\
\hline Batch accumulation, hours & 161.7 & 161.9 & 162.0 & 161.9 & 162.1 & 161.9 \\
\hline End of ship loading, hours & 187.1 & 186.7 & 187.0 & 186.6 & 187.6 & 187 \\
\hline Total costs, ML RUB & 9.276 & 9.227 & 9.276 & 9.227 & 9.276 & 9.256 \\
\hline
\end{tabular}

Based on five values obtained from the distribution of the random variables, one can find the mean values of the observed parameters and define confidence intervals. In particular, the mean value for the hours of batch accumulation is 161.9 , with a standard deviation of 0.2 hours. Thus, at a $95 \%$ confidence interval, the limits are [161.5; 162.3]. The average time (161.9) is approximately 6.8 days (Fig. 4). It was used in a further experiment to identify the related costs (Fig. 5).
Figure $\mathbf{5}$ is a screenshot from one run of the model, while the mean value of the total costs for storage and delivery of cargo to the port (9.256 ML RUB) was found on the grounds of five runs (Table 4). The average time for the ship processing is 25.1 hours with the standard deviation of 0.3 hours. It was found as a difference between the mean times of ship arrival (161.9) and end of the transshipment operations (187), both were identified from the output of the experiments (Table 4).
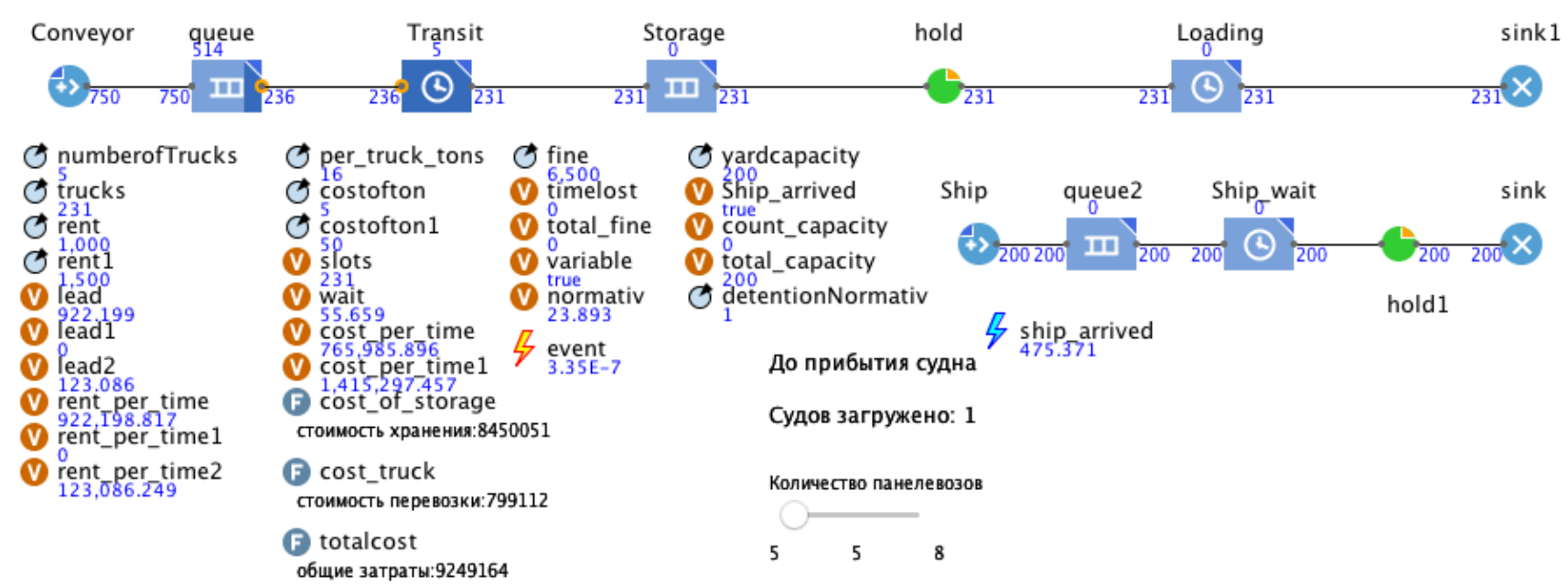

Figure 5 The screenshot of experiment 1 


\subsubsection{Experiment 2}

It is assumed that the cargo is brought not by a full ship's consignment (200) to the port as in the first scenario, but by parts ( 1 part - 160, second - 40). The time of transportation of the entire first part of the ship's consignment of panels $(160 * 4)$ was found with the help of the model (Table 5).

Based on the collected data, the mean value of batch accumulation (part A) is 129.4 hours with a standard deviation of 0.2 hours. Therefore, the $95 \%$ confidence interval would be $(127.2 ; 129.8)$ hours (Fig. 6). As can be seen from the figure, the first part of consignment ' $A$ ' is delivered by the time of the ship's arrival, and the second part (B) is supposed to be delivered later.

In this scenario, the parallel operations are provided partly. That is until the loading of the vessel by 2790 cubic meters of cargo $(186 * 3.75 * 4=2790$, Figure 6). During this time (from day 5.4 until day 6.3, Figure 5), the operations of ship loading are parallel to the process of delivery of the second part of a consignment to the port. Therefore, the cost before the beginning of the unparalleled operations (and calculation of a fine due to the demurrage of the ship) is relatively low, approximately 1.959 million Rubles (Fig. 7).

After 6.3 days, the ship is waiting for the arrival of the trucks with the cargo, related to the second part of the shipping consignment. Totally, 'B'- part of the shipping consignment is delivered by the model time - 164 hours or 6.71 days (Table 5). On average, it took 31.7 hours for the accumulation of $20 \%$-batch of shipping consignment in the port (Table 5).

Figure 7 shows that to ensure the uninterrupted loading of the vessel, it is required to make the last 14 visits (200$186=14$ ) on time so as to provide parallel operations. However, they took place at a time when the operations with the first part of the consignment had been already finished. Since those trips took place later, the fine for demurrage of the ship generated. Therefore, total costs with a fine due to a vessel awaiting the arrival of the cargo are on average 8.866 ML (Table 5).

Table 5 Output of the experiments, representing scenario 2

\begin{tabular}{|l|c|c|c|c|c|c|}
\hline Experiment & $\mathbf{1}$ & $\mathbf{2}$ & $\mathbf{3}$ & $\mathbf{4}$ & $\mathbf{5}$ & Mean \\
\hline $\begin{array}{l}\text { Batch accumulation (part A), } \\
\text { hours }\end{array}$ & 129.5 & 129.5 & 129.4 & 129.1 & 129.3 & 129.4 \\
\hline $\begin{array}{l}\text { Batch accumulation (part B), } \\
\text { hours }\end{array}$ & 31.5 & 31.3 & 31.7 & 32.1 & 31.8 & 31.7 \\
\hline $\begin{array}{l}\text { End of parallel operations } \\
\text { (ship loading and delivery of } \\
\text { cargo), hours }\end{array}$ & 153.0 & 152.7 & 152.6 & 152.7 & 152.8 & 152.8 \\
\hline End of ship loading, hours & 161.4 & 161.2 & 161.5 & 161.5 & 161.5 & 161.4 \\
\hline Total costs, ML RUB & 8.875 & 8.903 & 8.875 & 8.801 & 8.875 & 8.866 \\
\hline
\end{tabular}

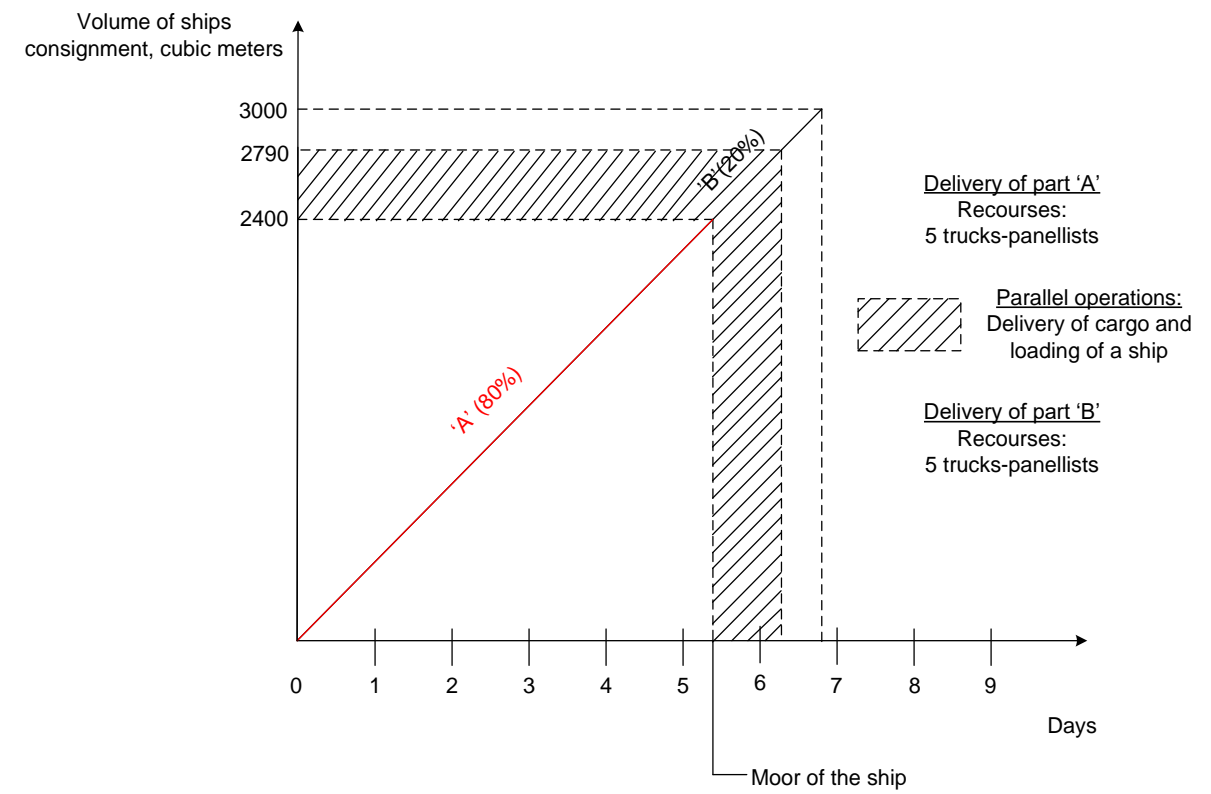

Figure 6 Scenario 2 - the first part of consignment ' $A$ ' $(80 \%)$ is delivered to the port before the ship arrival and 5 trucks-panellists are used 


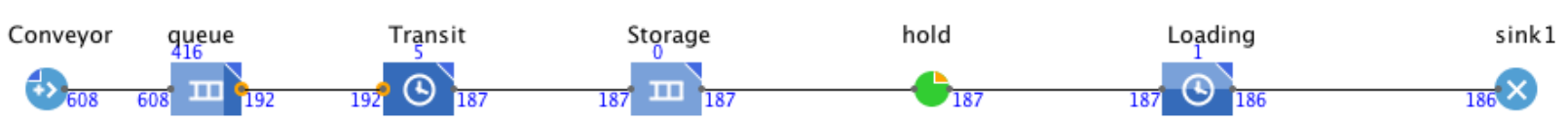
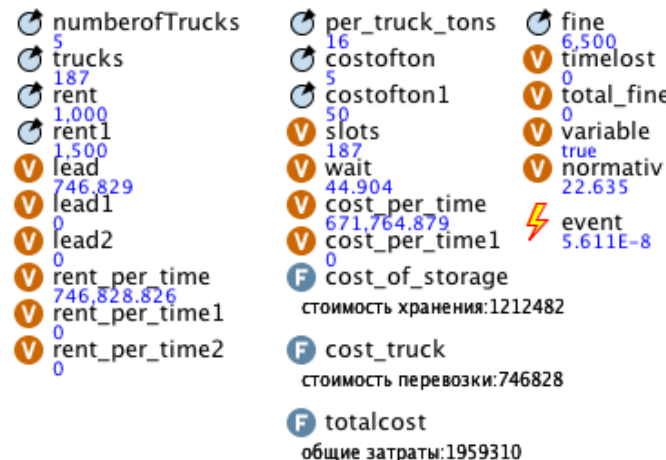

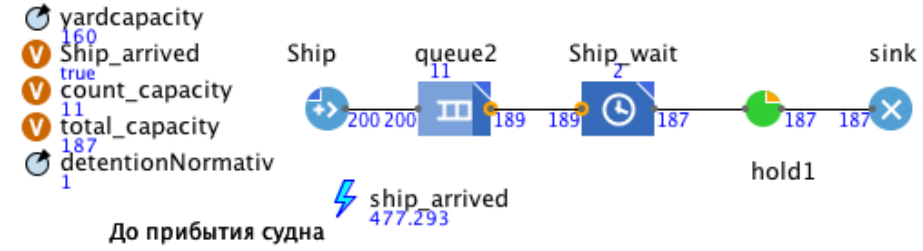

Судов загружено: 0

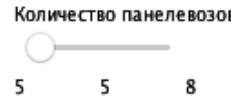

Figure 7 The screenshot of experiment 2 (before the fine was calculated)

\subsubsection{Experiment 3}

In this experiment, similar to experiment 2, the first part of the shipping consignment was equalled to $160(80 \%)$. However, to ensure the delivery of the second 20\%-part (40) of ship consignment on time, the number of trucks-panellists was increased from 5 to 8 after the arrival of the first part. In this case, the time for delivery of the first part of the ship's batch remained approximately, as in the previous experiment, i.e. on average 129.5 hours, since the first part of the consignment remained the same and was delivered to the port employing 5 trucks-panellists (Fig. 8).

For the delivery of the second part of the shipping consignment, additional trucks-panellists are used (Fig. 8). That is three, the cost of their exploitation increases since it is assumed that three panellists are not owned by the company. As a matter of fact, the cost of their operation is higher (1500 Rubles per hour instead of 1000 Rubles per hour).

Additional three panellists are the minimum necessary number, ensuring the delivery of the remaining consignment on time and providing parallel operations. The time for the accumulation of the remaining 20\%-batch of the shipping consignment is shorter (20.8 hours or by 150.3 hours of model time $(129.5+20.8)$, Table 6) than in scenario $2(31.7$ hours). That is why the total costs are also lower than in the second experiment: a mean value of 8.612 ML RUB (Table 6).

Table 6 Output of the experiments, representing scenario 3

\begin{tabular}{|l|c|c|c|c|c|c|}
\hline Experiment & $\mathbf{1}$ & $\mathbf{2}$ & $\mathbf{3}$ & $\mathbf{4}$ & $\mathbf{5}$ & Mean value \\
\hline Batch accumulation (part A), hours & 129.5 & 129.2 & 129.7 & 129.3 & 129.8 & 129.5 \\
\hline Batch accumulation (part B), hours & 22 & 20.8 & 20.4 & 20.3 & 20.3 & 20.8 \\
\hline End of ship loading, hours & 154.3 & 154.0 & 154.1 & 154.5 & 154.6 & 154.3 \\
\hline Total costs, ML RUB & 8.518 & 8.570 & 8.614 & 8.679 & 8.681 & 8.612 \\
\hline
\end{tabular}

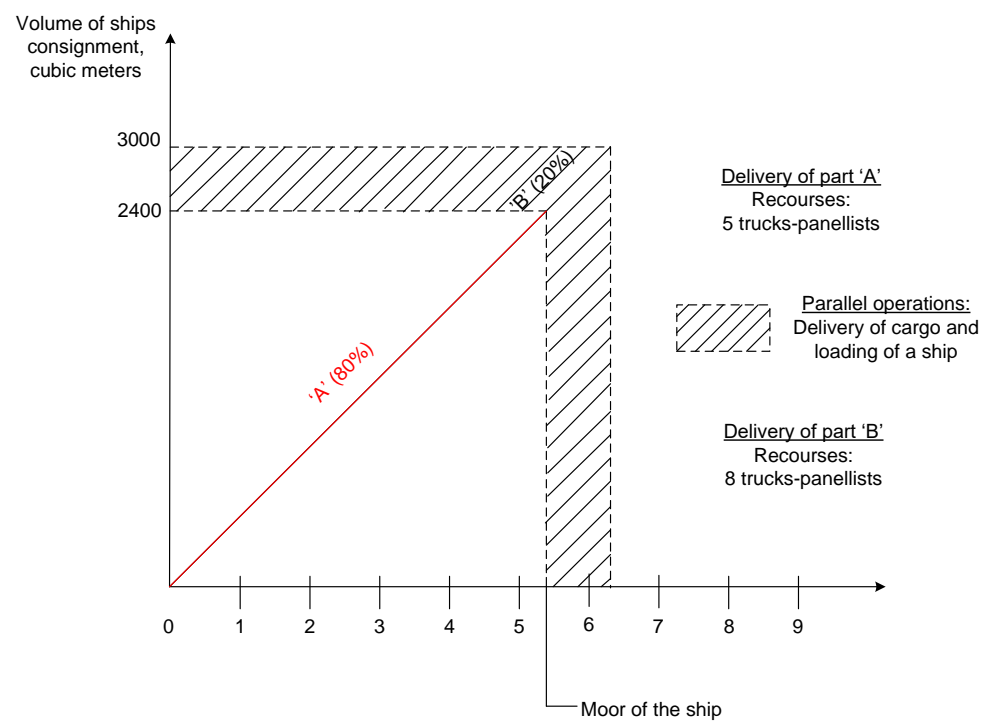

Figure 8 Scenario 3 - the first part of consignment 'A' $(80 \%)$ is delivered to the port before the ship arrival and additional number of trucks is used 


\subsubsection{Experiment 4}

An alternative option for the formation of the cargo base of the port of Ust-Luga was created by changing additional parameters in the $4^{\text {th }}$ experiment. It was assumed that the shipping consignment is delivered in two parts, but the first part is larger (170) than in the previous experiments (160). The required time for delivering the first part of shipping consignment to the port before the arrival of the vessel was found from the experiments (Table 7).

Based on the collected statistics, the mean value of $85 \%$-batch accumulation is 137.9 hours with a standard deviation of 0.2 hours (Fig. 9). The 5 truck-panellists, delivering the second part of the shipping consignment can deliver cargo on-time, ensuring parallel operations (i.e. while the second part is loading).

The trucks deliver ' $\mathrm{B}$ ' part of shipping consignment within 23.8 hours (Table 7). Parallel operations finish when the ship is loaded with 3000 cubic meters of cargo by the model time of 162.7 hours (or 6.8 days). As a result, fine for demurrage does not occur. Therefore, total costs are minimal, on average, 8.479 ML RUB (Table 7).

Table 7 Output of the experiments, representing scenario 4

\begin{tabular}{|l|c|c|c|c|c|c|}
\hline Experiment & $\mathbf{1}$ & $\mathbf{2}$ & $\mathbf{3}$ & $\mathbf{4}$ & $\mathbf{5}$ & Mean value \\
\hline $\begin{array}{l}\text { Batch accumulation (part A), } \\
\text { hours }\end{array}$ & 137.6 & 138.0 & 138.0 & 138.1 & 137.7 & 137.9 \\
\hline $\begin{array}{l}\text { Batch accumulation (part B), } \\
\text { hours }\end{array}$ & 24 & 24 & 23.7 & 23.5 & 23.9 & 23.8 \\
\hline End of the ship loading & 162.3 & 162.6 & 163.2 & 162.9 & 162.6 & 162.7 \\
\hline Total costs, ML RUB & 8.470 & 8.471 & 8.513 & 8.472 & 8.471 & 8.479 \\
\hline
\end{tabular}

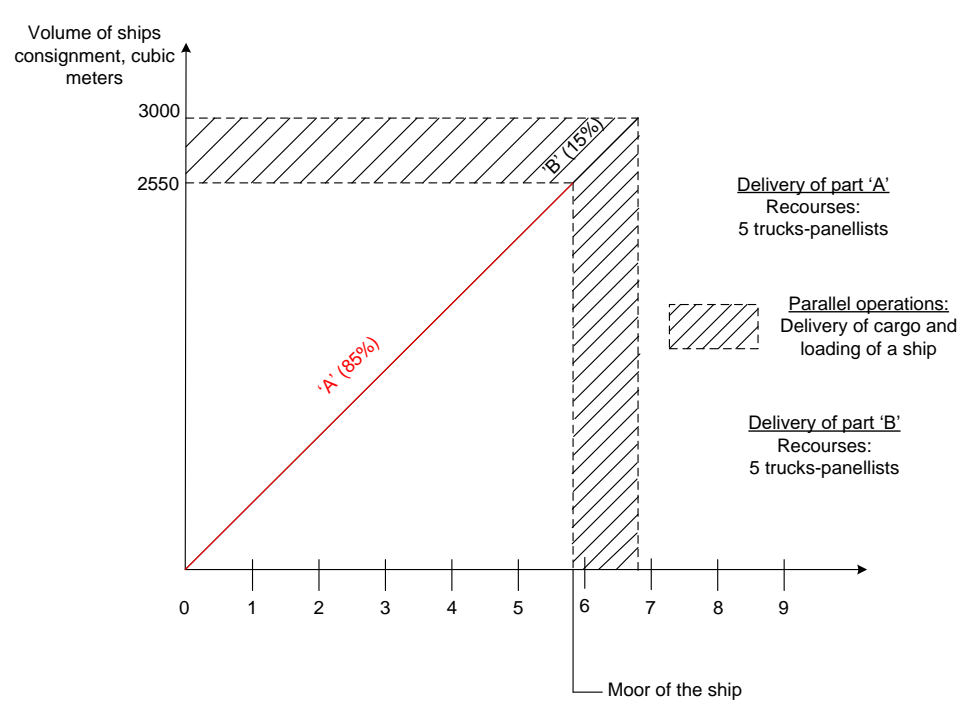

Figure 9 Scenario 4 - the first part of consignment 'A' $(85 \%)$ is delivered to the port before the ship arrival and five truck-panellists are used

\section{FINDINGS}

Based on the analysis of the model output, the best option for the organization of the integrated processes between the manufacturer and Ust-Luga port has been identified (Table 8).

As can be seen from the table, the minimal costs are associated with the $4^{\text {th }}$ experiment, when instead of delivering the whole ship consignment from the plant to the port before the arrival of the vessel (200), the consignment is delivered in two parts. Before the vessel arrives, the first part of ship consignment $(170$, i.e. $85 \%)$ is delivered to the port by the trucks-panellist. This option allows ensuring thorough continuity of ship loading and reduces fines due to time lost on waiting. The second part of ship consignment arrives during the loading of remaining cargo from the first consignment; such a parallel organization of work is provided by the minimal use of resources (5 truckspanellists). Therefore, the total costs are low (8.479 million Rubles). That is $8 \%$ less than in the first experiment, where the entire ship consignment is delivered to the port before the arrival of the vessel.
In addition, this option (the $4^{\text {th }}$ experiment) is $4 \%$ cheaper than the variant (the $2^{\text {nd }}$ experiment) with the delivery of the first $80 \%$ of the shipping consignment to the port (8.866 million Rubles, experiment 2). The reason for such difference is that when delivering the smaller first part of the ship consignment to the port, the entire second part of the ship batch $(20 \%)$ cannot be delivered on time, if the minimum number of resources is used ( 5 trucks). Therefore, continues loading operations with the ship cannot be provided, which leads to an unproductive idle time of the ship and additional costs due to fines. If to use a larger number of panellists (the $3^{\text {rd }}$ experiment), that is, in the case of leasing additional three trucks to deliver the remaining $20 \%$ of the shipping consignment from the plant to the port on time, then the total costs will be $3 \%$ higher than in the $4^{\text {th }}$ experiment. 
Table 8 Comparative analysis of the scenarios for integrated system (plant-port) organization

\begin{tabular}{|c|c|c|c|c|c|c|}
\hline Experiment & $\begin{array}{c}\text { Number of trips } \\
\text { to the port }\end{array}$ & Number of trucks & $\begin{array}{c}\text { Lead time } \\
\text { (part A), hours }\end{array}$ & $\begin{array}{c}\text { Lead time } \\
\text { (part B), hours }\end{array}$ & $\begin{array}{c}\text { Ship loading } \\
\text { time, hours }\end{array}$ & $\begin{array}{c}\text { Total costs, } \\
\text { MI RUB }\end{array}$ \\
\hline 1 & 200 & 5 & \multicolumn{2}{|c|}{$161.9^{*}$} & 25.1 & 9.256 \\
\hline 2 & $\begin{array}{c}160 \text { and } 40 \\
(80 \% \text { and } 20 \%)\end{array}$ & 5 & 129.4 & 31.7 & 32 & 8.866 \\
\hline 3 & $\begin{array}{c}160 \text { and } 40 \\
(80 \% \text { and } 20 \%)\end{array}$ & 5 and 8 & 129.5 & 20.8 & 24.8 & 8.695 \\
\hline 4 & $\begin{array}{c}170 \text { and 30 } \\
(85 \% \text { and 15\%) }\end{array}$ & 5 & 137.9 & 23.8 & 24.8 & 8.479 \\
\hline \multicolumn{7}{|r|}{ Note: *lead time for delivering an entire shipping consignment. } \\
\hline
\end{tabular}

\section{DISCUSSION}

Our findings suggest that favourable conditions for integrating Ust-Luga port-related process with the plant in its vicinity would be insufficient for the creation of the port of the third generation. The reason behind is that the problems of integrated development of the port and industrial infrastructure should be met by the multifaceted approach. It is associated with the theory and practice of locating industries, creating clusters and multiplicative effects in the development of industrial areas of the port. Above all, the development of the port and co-located manufactures is grounded on the logistics theory. In the framework of logistics methods and models (e.g. simulation modelling as advanced ones), the preferable option for the integrated organization of production and port-related processes has been identified.

In particular, the systematic view upon the integrated organization of production and transport-warehouse processes was provided based on the theory of planning and modelling of logistics systems. For this purpose, a simulation model, or so-called software-based re-creation of the real world in simplified form, has been proposed. The model represented a micro-logistic system: a factory for the production of reinforced concrete products (wall sandwich panels) connected with the port, through which the manufactured goods are subjected to the export.

It was proposed that the application of principles of integrated logistics serves as one of the main prerequisites for the development of the port to the third-generation phase, in which an efficient interaction between maritime processes and manufacturing plants, located in the vicinity and formed in clusters, is a fundamental detriment for the ports' further growth. To justify this statement, in the model, the main logistics processes have been optimized leading to a significant reduction of inventories, logistics costs, and growth of consumer satisfaction. Specifically, the integration of the production processes in the manufacturing plant (also considered as the future cargo base/source) with the port operations has been grounded on the methodological transition of the micro-logistics system (plant-port) to a 'pulling' type from its traditional 'pushing' type.

Because the logistics systems, which are 'pulling' by nature, use the just-in-time approach for the management of goods and information flows in the supply chains, this concept became a critical platform for the efficient interaction of manufacturing plant with the port. According to this concept, the materials transfer from the plant to the port can be organized in the form of the smooth process. That is to say, the delivery of the first part of the ship consignment ' $A$ ' from the plant to the port should be done by the time of the vessel arrival, while the remainder of the cargo (part ' $\mathrm{B}$ ' of shipping consignment) needs to be supplied to the port just at the required time, when the vessel is already moored to the berth and the consignment of cargo ' $\mathrm{A}$ ' is under transshipment to the vessel. In doing so, the process of transshipment can be continuous, facilitating the efficient use of the allocated resources (vessel, trucks, and cranes), reducing their dwelling time.

The current study contributes to the understanding of the necessary system of organization of all logistics processes effectively, from the producer (plant) to the consumer (port). That is why these findings partly guide to the elimination of one of the key organizational barriers, among others, such as the problems of poor equipment or obsolete technologies, in the port development to the next generation. To arrange the delivery of sandwich panels to the port from the plant in an effective manner, the simulation modeling can be used. The results from simulation modelling are more accurate in general, compared to the analytical model because this approach allows taking into account the probabilistic nature of the environment. Additionally, the model simplifies the planning of the logistics processes and time of their occurrence in the reverse order.

With the help of the model, firstly, it was necessary to determine the transit time to the port. Then, in the reverse order, taking into account the moment of the start of the discharge of the first batch at the port, the time for starting the loading of the further panel-trucks at the plant should be calculated, allowing for the loading capacities in the warehouse of the plant and at the port. If the shipping lot is large, then assuming the number of available trucks used to deliver cargo to the port, as well as the speed of transshipment, the next approach moment is calculated, based on which the loading time of the remaining trucks is determined. So as the total cost associated with delivering of cargo to the port was minimized, apart from required times, the necessary amount of resources (truck-panellist) should be found.

In particular, the outcome of the model showed that the first part of ship consignment (85\%) should be delivered to the port by the time of ship arrival, while the second part of ship consignment needs to be supplied during the loading of remaining cargo from the first consignment to ship; such a parallel organization of work is provided by the minimal use 
of resources ( 5 trucks-panellists). Thus, instead of delivering the whole ship consignment to the port before the arrival of the vessel ('pushing' type approach), the consignment should be delivered in two parts, following 'pulling' type of logistics system. This option allows ensuring thorough continuity of ship loading and eliminates fines due to time lost on waiting.

To achieve a balance of 'costs/service' during the process of delivering finished products from the producer to consumer, the application of JIT concept is suggested based on the findings from the modelled micro-logistics system. From this implication, it logically follows that great attention should be paid to issues of an organizational nature in the ports. These aspects have to be studied more intensively without diminishing the role of other issues, concerning the improvement of the technological processes, the replacement of the equipment and development of new technologies.

In conclusion, it worth to note that the application of JIT concept, which is natural for the 'pulling' type logistics system, was simply attained in the experiments with the model. It was done by the analyses of inputs and outputs and subsequent model adjustments. Meanwhile, in practice, the JIT concept is hard to apply. So far, there has not been any evidence in the literature that such quality practices had been undertaken even by ports of the fifth-generation (Tran et al., 2011).

\section{CONCLUSIONS AND FURTHER RESEARCH}

Although different logistics concepts can be used in the third-generation ports, the immediate goal of logistics can be attained by the application of one of the main strategies for integrated logistics planning in supply chains. That is a Justin-time concept used in the current case of delivering finished products from the plant to the seaport. Specifically, we argued that the micro-logistics system (plant-port) should be 'pulling' instead of 'pushing' type for the delivery of cargo from the plant to the port. For doing so, the supply chain management scheme has been described. Under such a scheme of organizing the interaction of participants in the logistics chain, a part of the cargo of ' $A$ ' size from the plant is shipped and delivered before the arrival of the vessel, the remaining part of the cargo ' $\mathrm{B}$ ' - when the vessel is already moored to the berth and the cargo ' $\mathrm{A}$ ' is transshipped. 'Pulling' approach for an interconnecting port-related process with plant guarantees minimization of logistics costs. In the case of 'pushing' type of the system, the entire ship consignment (not in parts), would be delivered to the port before the arrival of the vessel. However, this type of integration between a port and the plant would result is extensive use of the expensive port territories and entail other financial expenses.

The 'pulling' logistics-oriented organization of work involves planning the delivery of goods, starting from the consignee located in the port, i.e. based on its actual demand for the quantity and quality of the cargo, and further to the shipper (the plant). This corresponds to the 'pulling' type of production process control system, in which each subsequent technological section draws from the previous only the right amount of cargo for a particular consumer and at the right time (Panova, 2011; Panova et al., 2016).

Although previous findings indicated that quality management practices in terms of a just-in-time approach, quick response, lead-time management, lean and agile logistics (Tran et al., 2012; Lam and Song, 2013; Tran et al., 2011; Marlow and Casaca, 2003) are mostly suitable for the fifth stage of port evolution, our study followed a specific case showing that the need for such approaches already exists at the ports transiting to the third-generation phase. In the article, the port Ust-Luga located in the North-West Federal District of Russia has been considered, given the prospects for its ambitious development and analyzing its current stance.

It is expected that via the port of Ust-Luga large lots of sandwich panels from the plant will be exported to Sweden (or Finland). For the analysis of a micro-logistics system, represented by production enterprise interacting with the external environment (port), which, in turn, is characterized by the probabilistic nature of the work, modern methods of research were utilized. The use of simulation modelling in combination with the analytical models helped to conduct a comprehensive assessment of logistics processes, related to the coordination of supply of finished products from the plant to the port.

Previously, sufficient attention to these issues has not been given. According to recent studies (Tran et al., 2011), there has not been any evidence in the literature that such quality practices (e.g. JIT approach) had been undertaken by ports of the fifth generation. Our study showed the benefits derived from the application of this approach from a theoretical point of view. By the use of the created discreteevent model, which takes into account the principles of reducing overall costs and improving customer service, the most rational options of supplying goods from the manufacturer to the port have been determined.

Meanwhile, this study is not without limitations. First and foremost, it should be noted that the model output is quasi-optimal because the number of scenarios was restricted by the researcher. Thus, the preferable option of the organization of the integrated processes in the system (plantport) was identified from the limited number of alternatives rather than infinite variants checked in the optimization experiment.

However, this limitation did not reduce the quality of the research and the main finding. The experiments with model showed that the consignment should be delivered in two parts in the following manner: before the vessel arrives, the first part of ship consignment $(85 \%)$ is delivered to the port by the trucks-panellist. This option allows ensuring thorough continuity of ship loading and reduces fines on time lost in waiting. The second part of ship consignment arrives during the loading to ship the remaining cargo from the first consignment. Such a parallel organization of work is provided by the minimal use of resources (5 truckspanellists). Therefore, the total costs are $8 \%$ lower compared to the scenario, where the entire shipping consignment is delivered to the port before the arrival of the vessel (Table 8).

Future researchers should consider investigating the impact of risks on the smooth organization of the interconnection between the plant and port that work on the principles of JIT concept. Specifically, the contingency plans can be outlined to provide the resilience of 'pulling' logistic system. 


\section{REFERENCES}

Accenture.com (2016). Connected Ports driving future trade. Available at URL: https://www.accenture.com/t20161012T003018__w__/usen/_acnmedia/PDF-29/accenture-connected-ports-drivingfuture-trade.pdf Retrieved: 05.04.2019.

Andronov, S. A. (2013). The use of simulation for planning the Just in Time delivery. Proceedings of IMMOD-2013: Simulation modeling, theory and practice, Kazan, Russia, 30-36.

Angeliki, P. (2005). The Way a Third Generation Port Can Boost Local Employment: The Case of Piraeus. European Research Studies, 8(3-4), pp.22-44.

AnyLogic.ru (2019). About the program. Available at URL: http://www.anylogic.ru/ Retrieved: 8.02.2019.

Arumsari, S. S., Rachim, Y. M., \& Aamer, A. M. (2019). Factors of Kaizen Transferability in Non-Japanese Cultures. Proceedings of the 9th International Conference on Operations and Supply Chain Management, RMIT University, Vietnam.

Barlas, Y., \& Carpenter, S. (1990). Philosophical roots of model validation: two paradigms. System Dynamics Review, 6(2), pp.148-166.

Beškovnik, B., \& Twrdy, E. (2011). Agile port and intermodal transport operations model to secure lean supply chains concept. PROMET-Traffic\&Transportation, 23(2), pp.105112.

Betset.fi (2016). Official website of Betset. Available at URL: http://www.betset.fi/fi/info.html Retrieved: 01.06.17.

Bichou, K., \& Gray, R. (2004). A logistics and supply chain management approach to port performance measurement. Maritime Policy \& Management, 31(1), pp.4767.

Casaca, A. C. P. (2005). Simulation and the lean port environment. Maritime Economics \& Logistics, 7(3), pp.262280.

Dp.ru (2016a). Investments - The Finnish company Betset Oy sold a plant for the production of panels to investors from Kazakhstan. Business St. Petersburg-Online Gazette. Available at URL: https://www.dp.ru/a/2016/02/10/Evro_menjajut_na_tenge Retrieved: 01.06.17.

Dp.ru (2016b). Exports - Petersburg plant Betset began to export to Sweden panels for the construction of houses. Business St. Petersburg-Online Gazette. Available at URL: https://www.dp.ru/a/2016/10/31/Panelnij_jeksport Retrieved: 01.06.17.

Dybskaya, V.V., Zaitsev, E.I., Sergeev, V.I., Sterligova, A.N. (2008). Logistics: Integration and Optimization of Logistics Business Processes in Supply Chains, Eksmo Publishing House, Moscow, Russia.

Ekyalimpa, R., Werner, M., Hague, S., AbouRizk, S., \& Porter, N. (2016). A combined discrete-continuous simulation model for analyzing train-pedestrian interactions, Proceedings of the 2016 Winter Simulation Conference (IEEE Press), 1583-1594

Gonzalez-Aregall, M., Bergqvist, R., Monios, J. (2017). Port Initiated Measures for more Sustainable Transport -a Hinterland Perspective, Proceedings of the conference: Port Initiated Measures for more Sustainable Transport -a Hinterland Perspective, Madrid, Spain, 1-3.

Hesse, M., \& Rodrigue, J. P. (2004). The transport geography of logistics and freight distribution. Journal of transport geography, 12(3), pp.171-184.

Hilletofth, P., \& Lättilä, L. (2012). Agent based decision support in the supply chain context. Industrial Management \& Data Systems, 112(8), pp.1217-1235.

Isaeva, N.V. (2017). Formation of the Cargo Base of Ust-Luga Port with Allowance of the Principles of Integrated Logistics. Mater thesis, Petersburg State Transport University, Russia.
Jakomin, I. (2003). New function of seaports: Logistics and distribution. Promet-Traffic \& Transportation, 15(1), pp.1-5.

Kaigorodtsev, A. A., \& Rakhmangulov, A. N. (2009). Application of simulation modeling in the pre-project evaluation of the distribution center of the industrial enterprise, Proceedings of the IMMOD Conference: Simulation modeling, theory and practice, St. Petersburg, Russia, 2, 90-95.

Kaliszewski, A. (2018). Fifth and sixth generation ports (5GP, 6GP) - evolution of economic and social roles of ports. Available at URL: https://www.researchgate.net/publication/324497972_FIFT H_AND_SIXTH_GENERATION_PORTS_5GP_6GP__EVOLUTION_OF_ECONOMIC_AND_SOCIAL_ROLES _OF_PORTS Retrieved: 05.04.2019.

Karsaev, O. V., Morozov, B. M., Sabitov, R. A., \& Smirnova, G. S. (2016). Simulation modeling of relay delivery system. Vestnik of NCBZHD, 1, 45-56.

Kuznetsov, A. L., \& Galin A. V. (2015). Genesis of models of ports development in modern transport science. Vestnik of the State University of the Marine and River Fleet of Admiral S.O. Makarov, 2 (30), 141-152.

Lam, J. S. L., \& Song, D. W. (2013). Seaport network performance measurement in the context of global freight supply chains. Polish Maritime Research, 20(Special Issue), pp.4754.

Lam, J. S. L., \& Zhang, W. (2011). Analysis on development interplay between port and maritime cluster. Proceedings of the First International Workshop on Port Economics, National University of Singapore, 1-36.

Lättilä, L. (2012). Improving Transportation and Warehousing Efficiency with Simulation-Based Decision Support Systems. Doctoral thesis, Acta Universitatis Lappeenrantaensis, Finland.

Lee, P. T. W., \& Lam, J. S. L. (2015). Container port competition and competitiveness analysis: Asian major ports. In Handbook of ocean container transport logistics, Springer, Cham, Switzeland.

Lee, P. T. W., \& Lam, J. S. L. (2016). Developing the fifthgeneration ports model. In Dynamic shipping and port development in the globalized economy, Palgrave Macmillan, London, UK.

Lukinskiy, V. S. (2008). Models and Methods of Logistics Theory. Peter, St. Petersburg, Russia.

Lukinskiy, V.S., Lukinskiy, V.V., \& Pletneva, N.G. (2016b). Logistics and Supply Chain Management. Yurayt Publishing, Moscow, Russia.

Lukinskiy, V.S., Panova, Y., and Soletskiy, R. (2016a). Simulation modelling of supply chain with allowance of reliability. Russian Journal of Logistics and Transport Management, 3(2), pp.49-60.

Madani, S. (2018). Global Seaport Competitiveness: a Resource Management Perspective. Thesis for Doctor of Philosophy, RMIT University, Melbourne, Australia.

Makrushina, E.A. (2016). The role of the port-industrial cluster of Ust-Luga in the spatial development of the region, Internetjournal "Naukovedenie", 8(2), Available at URL: https://cyberleninka.ru/article/v/rol-portovopromyshlennogo-klastera-ust-lugi-v-prostranstvennomrazvitii-regiona Retrieved: 02.06.17.

Marlow, P. B., \& Casaca, A. C. P. (2003). Measuring lean ports performance. International journal of transport management, 1(4), pp.189-202.

Montwiłt, A. (2014). The role of seaports as logistics centers in the modelling of the sustainable system for distribution of goods in urban areas. Procedia-Social and Behavioral Sciences, 151, pp.257-265.

Neustroeva, N.A. (2011). Mechanisms of the formation of industrial clusters. Russian Entrepreneurship. 5, pp.52-56. 
Notteboom, T. E., \& Winkelmans, W. (2001). Structural changes in logistics: how will port authorities face the challenge? Maritime Policy \& Management, 28(1), pp.71-89.

Notteboom, T., \& Rodrigue, J. P. (2008). Containerisation, box logistics and global supply chains: The integration of ports and liner shipping networks. Maritime Economics \& Logistics, 10(1-2), pp.152-174.

Notteboom, T., and Yang, Z. (2017). Port governance in China since 2004: Institutional layering and the growing impact of broader policies. Research in Transportation Business \& Management, 22, pp.184-200.

Paixão, A. and Marlow, P. (2003). Fourth generation ports - a question of agility? International Journal of Physical Distribution and Logistics Management, 33, pp.356-357.

Panayides, P. M., \& Song, D. W. (2009). Port integration in global supply chains: measures and implications for maritime logistics. International Journal of Logistics: Research and Applications, 12(2), pp.133-145.

Panova Y., Isaeva, N. and Mukhtar, U. (2016). Formation of the cargo base of Ust-Luga port with allowance of the principles of integrated logistics. Russian Journal of Logistics and Transport Management, 2 (3), pp.23-35.

Panova, Y. (2011). Potential of Connecting Eurasia through TransSiberian Railway. International Journal of Shipping and Transport Logistics, 3(2), pp.227-244.

Panova, Y. (2016). Public-private partnership investments in dry ports - Russian logistics markets and risks. Doctoral thesis, Lappeenranta University of Technology, Lappeenranta, Finland.

Panova, Y. and Hilletofth, P. (2018). Managing supply chain risks and delays in construction project. Industrial Management \& Data Systems, 118 (7), pp.1413-1431.

Panova, Y. and Isaeva, N. (2016). Prospects of improving the role of maritime transport in the national economy, Proceedings of the conference 'Port-Oriented Logistics - 2016', State University of the Marine and River Fleet named after Admiral S.O. Makarova, St. Petersburg, Russia.

Rodrigue, J.-P. (2008). The Thruport concept and transmodal rail freight distribution in North America. Journal of Transport Geography, 16(4), pp.233-246.
Roso, V. (2009). The Dry Port Concept, Doctoral Thesis, Chalmers University of Technology, Göteborg, Sweden.

Russia's Merchant Seaports Association (2019). All cargoes of Russia. Journal of Seaports, 1(172), pp.70-78.

Sterman, J.D. (2000), Business Dynamics: Systems Thinking and Modelling for a Complex World, USA: McGraw-Hill.

Song, D. W., \& Panayides, P. (2012). Maritime logistics: a complete guide to effective shipping and port management, Kogan Page Publishers, London, UK.

Song, D. W., \& Panayides, P. M. (2008). Global supply chain and port/terminal: integration and competitiveness. Maritime Policy \& Management, 35(1), pp.73-87.

Suslov, S. A. (2009). Business is a field for experiments, but it is better to conduct them on a simulation model. Rational Enterprise Management, 4, pp.15-17.

Tran, H., Cahoon, S. and Che, S-L. (2012). Quality management for seaports integrated in supply chains. Int. J. Shipping and Transport Logistics, 4(4), pp.376-388.

Tran, H., Cahoon, S., \& Chen, S. L. (2011). A quality management framework for seaports in their supply chains in the $21 \mathrm{st}$ century. The Asian Journal of Shipping and Logistics, 27(3), pp.363-386.

Tran, H., Cahoon, S., \& Chen, S. L. (2012). Quality management for seaports integrated in supply chains. International Journal of Shipping and Transport Logistics, 4(4), pp.376392.

UNCTAD (1999). The fourth-generation port, UNCTAD Ports Newsletter, 1999, No. 19, p. 10, Available at URL: http://unctad.org/en/ Docs/posdtetibm15.en.pdf Retrieved: 05.04 .2019

Unescap.org (2019). Value-added services of logistics centres in port areas. Available at URL: https://www.unescap.org/sites/default/files/pub_2194_ch3.p df Retrieved: 15.03.2019.

Vincera-spb.ru (2016). Delivery of goods from Sweden to Russia. Available at URL: http://vincera-spb.ru/dostavka-sbornykhgruzov/iz-shvetsiiRetrieved: 20.09.2016.

Waters, D. (2009). Supply Chain Management: An Introduction to Logistics, Palgrave, London, UK.

PhD Yulia Panova is an Associate Professor at Luoyang Normal University in China. She used to work in National Research University Higher School of Economics and Emperor Alexander I St. Petersburg State Transport University, where she accomplished her post-graduate studies in 2012. In Lappeenranta University of Technology (Finland), she conducted an additional $\mathrm{PhD}$ research (2013-2016), concerning dry port public-private partnership investments and risk management methods. Miss Panova holds several international publications in the field.

Per Hilletofth (PhD) is a Professor of Operations and Supply Chain Management at Jönköping University in Sweden. He holds a PhD in Technology Management and Economics (with specialization in Logistics and Transportation Management) from Chalmers University of Technology (Sweden). His research focuses on operations and supply chain management with an emphasis on strategy, shoring, sourcing, demand and supply planning, information systems, and sustainability. He has published articles in various international journals including Industrial Management and Data Systems, Expert Systems with Applications, International Journal of Shipping and Transport Management, and European Business Review. He is currently in the Editorial Board for Industrial Management and Data Systems, World Review of Intermodal Transportation Research, International Journal of Logistics Economics and Globalization, and International Journal of Management in Education.

Arina Panova is a MSc student at ITMO University, Russia. She graduated from Baltic States University, where received a bachelor's degree. Her diploma's objective problem was addressed to overcome barriers in the wide application of drones for different spheres, including warehousing and transportation, mining, agriculture. Also, she took part in the international scientific-practical conference "Physical, mathematical and technical sciences as a post-industrial foundation for the development of the information society" with the focus on speed measurement system for the automatic landing of drones.

Xu Hongsheng is an Associate Professor at Luoyang Normal University and Henan Key Laboratory for Big Data Processing \& Analytics of Electronic Commerce, China. He is an expert in artificial intelligence, data mining, knowledge discovery, the Semantic Web and has several international publications in the field of expertise. 